\begin{tabular}{|c|c|c|}
\hline $\begin{array}{l}\text { OPEN ACCESS } \\
\text { Vol. } 1 \text { No. 2: 24-31 } \\
\text { Tahun 2018 } \\
\text { Artikel penelitian 固 }\end{array}$ & $\begin{array}{l}\text { Jutroal Alkuatilklestari } \\
\text { E-ISSN: 2598-8204 } \\
\frac{\text { https://ojs.umrah.ac.id/index.php/akuatiklestari }}{\text { DOI : https://doi.org/10.31629/.v1i2.2293 }}\end{array}$ & $Q=$ \\
\hline
\end{tabular}

\title{
Tingkat Keberhasilan Transplantasi Karang Acropora millepora (Ehrenberg, 1834) di Perairan Banyan Tree Lagoi, Bintan
}

\author{
The Success Rate of Tranplantation Acropora millepora (Ehrenberg, 1834) in Banyan Tree Lagoi \\ Lagoi, Bintan
}

\section{Mulyadi $^{\circledR}{ }^{\bowtie}$, Tri Apriadi1 ${ }^{1}$, Dedy Kurniawan ${ }^{1}$}

1 Manajemen Sumberdaya Perairan, Fakultas Ilmu Kelautan dan Perikanan, Universitas Maritim Raja Ali Haji, Tanjungpinang, Indonesia 29111

\section{$\square$ Info Artikel:}

Diterima: 25 April 2018

Revisi: 29 April 2018

Disetujui: 17 Mei 2018

Dipublikasi: 30 Mei 2018

\section{Keyword:}

Acropora millepora, Tranplantasi

Karang, Pertumbuhan Karang

\section{$\square$ Penulis Korespondensi:}

Mulyadi

Manajemen Sumberdaya Perairan,

Fakultas IImu Kelautan dan Perikanan,

Universitas Maritim Raja Ali Haji,

Tanjungpinang, Indonesia 29111

Email: mulyadi.msp2011@gmail.com

\begin{abstract}
ABSTRAK. Penelitian ini dilakukan dengan tujuan untuk mengetahui pengaruh ukuran fragmen yang berbeda terhadap pertumbuhan karang Acropora millepora dengan teknik transplantasi untuk mendapatkan ukuran fragmen optimal. Penelitian telah dilaksanakan pada bulan November 2017 sampai Februari tahun 2018 di Perairan Banyan Tree Lagoi Kabupaten Bintan. Media tranplantasi yang digunakan adalah balok persegi panjang dalam bentuk bagan persegi empat. Ukuran Fragmen karang Acropora millepora diberi 5 perlakuan yaitu $2 \mathrm{~cm}, 4 \mathrm{~cm}, 6 \mathrm{~cm}, 8 \mathrm{~cm}, 10$ $\mathrm{cm}$, dengan 5 kali pengulangan. Pertumbuhan mutlak pada frgamen $2 \mathrm{~cm}, 4 \mathrm{~cm}, 6 \mathrm{~cm}, 8 \mathrm{~cm}$ dan $10 \mathrm{~cm}$ sebesar $0,63 \mathrm{~cm}, 0,93 \mathrm{~cm}, 1,47 \mathrm{~cm}, 2,10 \mathrm{~cm}$ dan $1,10 \mathrm{~cm}$. Laju pertumbuhan pada frgamen $2 \mathrm{~cm}, 4 \mathrm{~cm}, 6 \mathrm{~cm}, 8 \mathrm{~cm}$, dan $10 \mathrm{~cm}$ sebesar $0,21 \mathrm{~cm}, 0,31 \mathrm{~cm}, 0,49 \mathrm{~cm}, 0,0,70 \mathrm{~cm}, 0,36 \mathrm{~cm}$. Analisis data dengan uji One-Way ANOVA menunjukkan pertumbuhan mutlak tinggi dan laju pertumbuhan tinggi karang Acropora millepora terdapat pengaruh yang nyata terhadap perlakuan ukuran fragmen yang berbeda $(p<0,05)$. dan dilanjutkan dengan Duncan didapat tingkat kelangsungan hidup pada masing-masing fragmen memilki tingkat kelangsungan hidup yang sama sebesar 60\%. Fragmen optimal karang Acropora millepora dicapai oleh ukuran tinggi $8 \mathrm{~cm}$ dengan pola pertumbuhan vertikal dan sebagai pertumbuhan karang yang efisien dan efektif dalam pemanfaatan secara berkelanjutan.
\end{abstract}

ABSTRACT. This study was conducted to determine the effect of different fragment sizes on Acropora milepora growth with transplantation to obtain optimal fragment size. This study was start from November 2017 to February 2018 at Banyan Tree Bintan Resort, Lagoi, Bintan Regency. The tranplan media used in this study was plant the fragments of coral at long concrete block with rectangle shape. The sizes of fragments of Acropora millepora with treatment were $2 \mathrm{~cm}, 4 \mathrm{~cm}, 6$ $\mathrm{cm}, 8 \mathrm{~cm}$, and $10 \mathrm{~cm}$ with 5 times repetition. The absolute growth for fragments $2 \mathrm{~cm}, 4 \mathrm{~cm}, 6 \mathrm{~cm}$, $8 \mathrm{~cm}$, and $10 \mathrm{~cm}$ is $0,63 \mathrm{~cm}, 0,93 \mathrm{~cm}, 1,47 \mathrm{~cm}, 2,10 \mathrm{~cm}$, and $1,10 \mathrm{~cm}$. The growth rate for fragments $2 \mathrm{~cm}, 4 \mathrm{~cm}, 6 \mathrm{~cm}, 8 \mathrm{~cm}$, and $10 \mathrm{~cm}$ is $0,21 \mathrm{~cm}, 0,31 \mathrm{~cm}, 0,49 \mathrm{~cm}, 0,70 \mathrm{~cm}$, and 0,36 cm. One-Way ANOVA was used for data analysis and shown that absolute growth and growth rate of Acropora millepora have significant effect on difference size of fragments $(p<0,05)$. With Duncan, the survival rate for each fragment is $60 \%$. The optimal size of Acropora millepora for transplantation is $8 \mathrm{~cm}$ with vertical growth pattern and as efficient for sustainability.

How to cite this article:

Mulyadi, Apriadi, T., \& Kurniawan, D. (2018). Tingkat Keberhasilan Transplantasi Karang Acropora millepora (Ehrenberg, 1834) di Perairan Banyan Tree Lagoi, Bintan. Jurnal Akuatiklestari. 1(2): 24-31. https://doi.org/10.31629/.v1i2.2293

\section{PENDAHULUAN}

Banyan Tree Bintan terletak di kawasan perairan wisata lagoi yang terletak Kabupaten Bintan Kepulauan Riau. Banyan Tree merupakan salah resort yang mempunyai Departement CSR (Conservation Lab) yang memiliki laboratorium konservasi dengan berbagai program pelestarian sumberdaya alam dengan konsep melindungi dan melestarikan tanpa merusak segala isinya.

Terumbu karang di sekitar perairan Banyan Tree telah dimonitoring oleh Conservation Lab sejak tahun 2012 sampai tahun 2015. Terumbu karang dalam kondisi baik walaupun dari tahun ke tahun mengalami penurunan, kondisi terumbu karang di sekitar perairan Banyan Tree Lagoi mengalami penurunan tutupan yang dratis. Hal ini disebabkan pada tahun 
2016 di sekitar perairan Banyan Tree Lagoi mengalami kenaikan suhu yang menyebabkan terjadinya coral bleaching. Conservation Lab mencatat kenaikan suhu di sekitar perairan Banyan Tree Lagoi dimulai dari bulan Maret yaitu $32-33^{\circ} \mathrm{C}$ dan kembali normal pada akhir bulan Agustus di suhu $31{ }^{\circ} \mathrm{C}$. Puncak bleaching diperkirakan terjadi pada bulan Juni dimana karang memutih di sekitar perairan Banyan Tree Lagoi Kabupaten Bintan hampir mencapai 90 \% (Anggara, 2016).

Melihat dari kenyataan di atas maka perlu dilakukan rehabilitasi terumbu karang di sekitar perairan Banyan Tree Lagoi. Rehabilitasi yang dilakukan dengan tranplantasi karang melalui pemotongan terumbu karang hidup yang selanjutnya di tanam di tempat yang mengalami kerusakan pada lahan kosong untuk menciptakan habitat baru (Kurniawan, 2011). Dalam melakukan tranplantasi karang pada suatu daerah sangat dikawatirkan akan merugikan daerah itu sendiri jika dilakukan dengan cara yang tidak tepat untuk memanfaatkannya. Oleh karena itu, diperlukan strategi dan prosedur yang tepat dalam melakukan kegiatan transplantasi karang.

Penelitian ini dilakukan untuk mengetahui ukuran fragmen karang Acropora millepora hasil tranplantasi yang paling optimal pertumbuhannya agar tidak menyebabkan eksploitasi berlebihan dan menciptakan efesiensi dan efektifitas dalam tranplantasi karang.

\section{BAHAN DAN METODE}

\section{2.l. Waktu dan tempat}

Penelitian ini dilaksanakan selama 3 bulan dimulai dari bulan November 2017 hingga bulan Februari 2018 yang berlokasi di Perairan Banyan Tree Lagoi Kabupaten Bintan. Peta penelitian dapat dilihat pada Gambar 1.

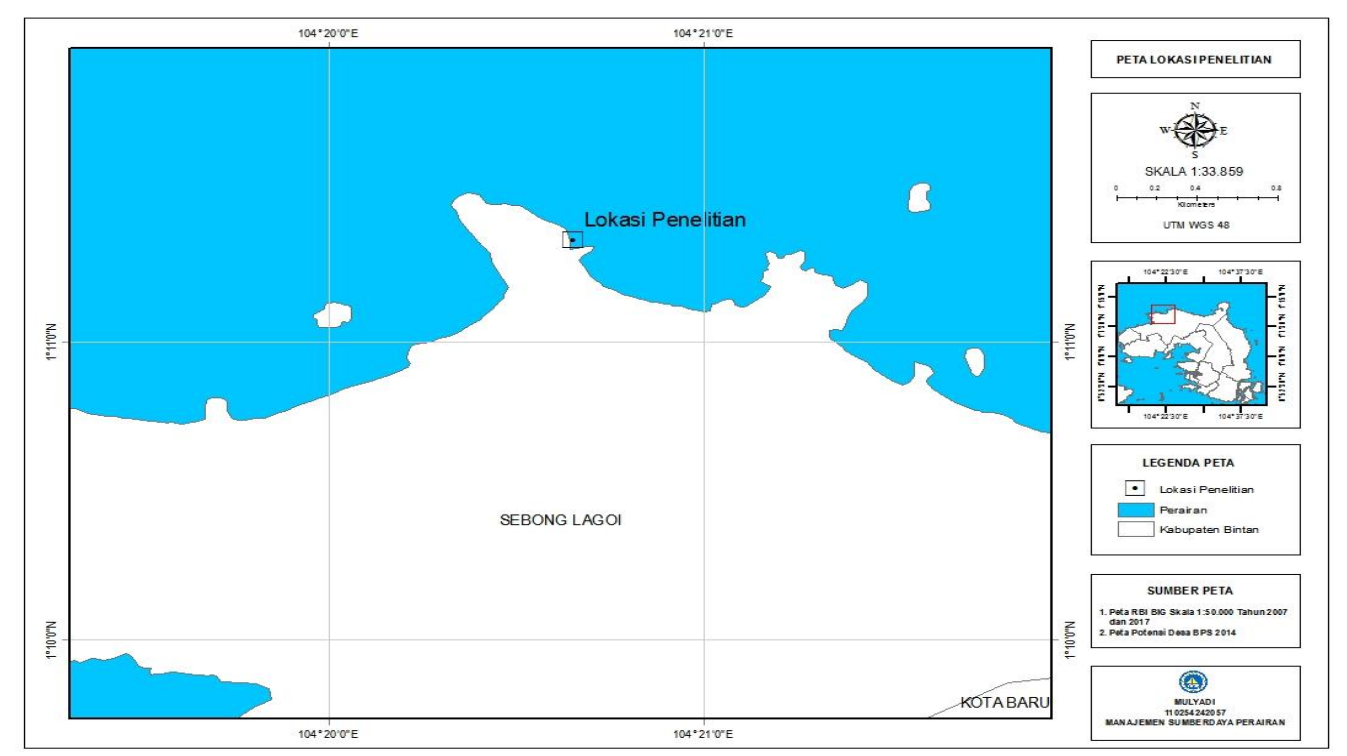

Gambar 1. Peta Lokasi Penelitian

\subsection{Alat dan Bahan}

Alat yang digunakan adalah peralatan selam SCUBA, kamera underwater, kertas sabak, jangka sorong, GPS, laptop, kabel ties, secchi disk, multi tester, tali, pelampung dan stopwatch, salt meter, turbidity meter. Bahan yang digunakan adalah sampel karang Acropora millepora, semen,epoxy, pasir dan air laut. Media yang digunakan adalah balok persegi panjang dalam bentuk bagan persegi empat. Ukuran fragmen karang Acropora yang digunakan diberi 5 perlakuan yaitu $2 \mathrm{~cm}$, $4 \mathrm{~cm}, 6 \mathrm{~cm}, 8 \mathrm{~cm}, 10 \mathrm{~cm}$ dengan 5 ulangan.

\subsection{Prosedur Penelitian}

Penelitian ini dilakukan dengan menggunakan metode kerja yaitu melalui tahap persiapan, pelaksanaan, pengamatan dan monitoring. Tahap persiapan terdiri dari menentukan jenis dan asal fragmen, pemilihan lokasi, pembuatan dan peletakan substrat, rancangan penebaran fragmen karang, transplantasi. Tahap pelaksanaan terdiri dari pemilihan dan pemotongan karang, peletakan fragmen pada substrat sementara tahap pengamatan terhadap pertumbuhan fragmen karang yang sudah ditanam dilakukan 1 bulan sekali selama 3 bulan dengan pengontrolan secara intensif.

\subsection{Teknik Pengumpulan Data}

Monitoring pertumbuhan karang dilakukan dengan car amengukur tinggi fragmen karang sementara pengukuran kualitas air dilakukan 1 bulan sekali selama 3 bulan diukur langsung pada penelitian dengan parameter yang di ukur adalah kecerahan, kedalaman, suhu, kecepatan arus, salinitas, kekeruhan, DO, pH. 


\subsection{Analisis Data}

Untuk menghitung pencapaian pertumbuhan karang yang ditransplantasikan dari data hasil pengukuran dilakukan dengan menggunakan rumus sebagai berikut:

Pertumbuhan Mutlak Tinggi Karang (Hermanto, 2015).

$$
\beta L=L t-L o
$$

Keterangan :

$\beta \mathrm{L}=$ pertumbuhan mutlak tinggi $(\mathrm{cm})$

Lt = Rata-rata tinggi akhir penelitian $(\mathrm{cm})$

Lo $=$ Rata-rata tinggi awal penelitian $(\mathrm{cm})$

Laju Pertumbuhan Tinggi Karang (Tioho \& Karauwan, 2014).

$$
P=\frac{L t-L o}{t}
$$

\section{Keterangan :}

$\mathrm{P}=$ Capaian pertumbuhan karang (cm per bulan)

Lt = Rata-rata tinggi/panjang pada akhir penelitian $(\mathrm{cm})$

Lo = Rata-rata tinggi/panjang pada awal penetian $(\mathrm{cm})$

$\mathrm{T}=$ Waktu pengamatan (bulan)

Tingkat Kelangsungan Hidup Karang (Prastiwi et al. 2012).

$$
S R=\frac{N t}{N 0} \times 100 \%
$$

Keterangan:

SR = Tingkat Kelangsungan Hidup

$\mathrm{Nt}=$ Jumlah individu pada akhir penelitian

NO = Jumlah individu pada awal penelitian

Analisis data yang diperoleh dari hasil pengamatan langsung dilapangan dianalisis secara kuantitatif. Hasil perhitungan dan tabulasi data pertumbuhan mutlak tinggi, laju pertumbuhan dan tingkat kelangsungan hidup karang pada ukuran fragmen yang berbeda setiap parameter untuk setiap perlakuannya dianalisis dengan uji One-Way Anova dan Post Hoc Duncan pada tingkat ketelitian 95\% dengan menggunakan program Statistical Produk And Service Solution (SPSS) dengan memasukan data fragmen karang yang masih tersisa diakhir penelitian.

\section{HASIL DAN PEMBAHASAN}

\subsection{Kondisi Kualitas Perairan Banyan Tree Lagoi}

Parameter yang diukur dalam penelitian ini meliputi, kecerahan, kedalaman, suhu, kecepatan arus, salinitas, kekeruhan, oksigen terlarut, dan derajat keasaman. Hasil pengukuran parameter kualitas air di lokasi penelitian disajikan pada Tabel 1.

Tabel 1. Kondisi Kualitas Perairan Banyan Tree Lagoi

\begin{tabular}{ccccccccc} 
Sampling & $\begin{array}{c}\text { Kecerahan } \\
(\mathrm{m})\end{array}$ & $\begin{array}{c}\text { Kedalaman } \\
(\mathrm{m})\end{array}$ & $\begin{array}{c}\text { Suhu } \\
\left({ }^{\circ} \mathrm{C}\right)\end{array}$ & $\begin{array}{c}\text { Kecepatan } \\
\text { arus }(\mathrm{m} / \mathrm{s})\end{array}$ & $\begin{array}{c}\text { Salinitas } \\
(\mathrm{ppm})\end{array}$ & $\begin{array}{c}\text { Kekeruhan } \\
(\mathrm{NTU})\end{array}$ & $\begin{array}{c}\mathrm{DO} \\
(\mathrm{mg} / \mathrm{L})\end{array}$ & $\begin{array}{c}\mathrm{pH} \\
\text { Bulan I }\end{array}$ \\
2,01 & 8,1 & 28,9 & 0,15 & 31,1 & 7,57 & 7,5 & 8,62 \\
Bulan II & 2,35 & 7,8 & 30 & 0,13 & 31 & 7,5 & 7 & 8,54 \\
Bulan II & 2,59 & 7,1 & 31 & 0,10 & 31 & 7,21 & 6,8 & 8 \\
Rata-rata & 2,32 & 7,67 & 29,97 & 0,13 & 31,03 & 7,43 & 7,10 & 8,39 \\
Baku Mutu* & $>5$ & - & $28-30$ & - & $30-33$ & 45 & $>5$ & $7-8,5$ \\
\hline
\end{tabular}

* Keputusan Menteri Lingkungan Hidup No 51 tahun 2004 tentang Baku Mutu Air Laut untuk Biota Laut.

Kecerahan perairan berkisar antara 2,01-2,59 m dengan rata-rata 2,32 m. Hal ini menunjukan kecerahan pada lokasi penelitian ini tidak sesuai dengan baku mutu, karena menurut Kepmen LH No 51 Tahun 2004, baku mutu kecerahan untuk kehidupan biota karang adalah lebih dari 5 meter. Kecerahan merupakan pengaruh terhadap cahaya yang masuk pada perairan yang di butuhkan zooxanthallae bersimbiosis dengan karang pada proses fotosintesis (Kurniawan, 2014).

Kedalaman perairan pada lokasi penelitian berkisar 7,1-8,1 m dengan rata-rata 7,67m. Menurut hasil penelitian Kambey (2013), kedalaman yang pertumbuhan panjang yang mengalami peningkatan setiap bulannya terdapat pada 
kedalaman $6 \mathrm{~m}$ dibandingkan kedalaman 3m dan 9m. Jika mengacu pada penelitian Kambey (2013) bahwa kedalaman pada penelitian ini kurang optimal untuk proses pertumbuhan karang Acropora sp.

Suhu perairan pada lokasi penelitian berkisar $28,9-31^{\circ} \mathrm{C}$ dengan rata-rata $29,97^{\circ} \mathrm{C}$, suhu perairan pada lokasi penelitian sesuai dengan baku mutu. Suhu sangat mempengaruhi pertumbuhan karang, jika terjadi penurunan maupun kenaikan satu derajat saja dapat mempengaruhi keberadaan zooxanthellae yang berada didalam jaringan karang (Kurniawan et al., 2017). Jika suhu suatu perairan naik melebihi standar baku mutu untuk kehidupan karang, maka bisa menyebabkan terganggu proses fotosintesis karang dengan keluarnya zooxanthellae dari jaringan karang dan pigmen karang akan menjadi putih yang disebut bleaching.

Kecepatan arus di lokasi penelitian berkisar antara 0,1-0,15 m/s dengan rata-rata 0,13 m/s. Arus merupakan sirklus air yang sangat penting bagi organisme yang hidup didalam perairan, di karenakan pergerakan siklus arus bagi karang untuk memperoleh makanan dalam bentuk zooplankton dan oksigen serta untuk membersihkan permukaan karang dari sedimen (Kurniawan et al., 2017).

Kondisi salinitas di lokasi penelitian berkisar antara 31-31,1 ppm dengan rata-rata 31,03 ppm. Dengan kisaran tersebut nilai salinitas masih sesuai dengan baku mutu yang itu kisaran 30-33ppm. Daya tahan terhadap salinitas setiap terumbu karang tidak sama satu sama lainnya. Sedangkan kekeruhan perairan pada lokasi penelitian berkisar antara 7,21-7,5 NTU dengan rata-rata sebesar 7,45 NTU. Tingkat kekeruhan tergolong tinggi di akibatkan pada bulan Desember 2017 dan Januari 2018 yang di pengaruhi oleh musim utara.

Oksigen terlarut (DO) berada pada kisaran 6,8-7,5 mg/L dengan rata-rata oksigen terlarut sebesar 7,10 mg/L, Dengan kisaran tersebut menunjukan Oksigen terlarut pada perairan penelitian ini masih berada dalam standar baku mutu perairan sesuai Kepmen LH No 5l Tahun 2004 tentang baku mutu air laut untuk karang. Kadar oksigen terlarut biasa dijadikan ukuran untuk menentukan mutu air. Kadar oksigen terlarut untuk karang lebih besar dari $5 \mathrm{mg} / \mathrm{l}$.

Derajat keasaman $(\mathrm{pH})$ perairan berkisar antara 8,0-8,62 dengan rata-rata sebesar 8,39. Nilai tersebut masih sesuai dalam batas abku mutu perairan laut menurut Kepmen LH No 5l Tahun 2004 tentang biota laut. Derajat Keasaman (pH) sangat penting sebagai parameter kualitas perairan karena dengan mengetahui nilai $\mathrm{pH}$ suatu perairan kita akan tahu apakah perairan tersebut sesuai atau tidaknya untuk menunjang kehidupan para biota yang hidup di perairan tersebut (Kurniawan, 2014).

Mengacu pada Kepmen LH No 51 (2004) bahwa parameter yang memenuhi baku mutu diantaranya yakni suhu, salinitas, oksigen terlarut, serta derajat keasaman perairan. Sedangkan parameter yang tidak memenuhi baku mutu diantaranya kecerahan, dan kekeruhan perairan. Artinya, kecerahan perairan di lokasi penelitian tergolong rendah sedangkan kekeruhannya tergolong tinggi.Kondisi ini sangat tidak mendukung kehidupan terumbu karang, sebagaimana diketahui bahwa karang sangat membutuhkan cahaya untuk melakukan fotosintesis oleh polip karang (zooxhantellae). Jika kondisi kecerahan perairan dan kekeruhan yang tidak memenuhi baku mutu, maka akan mempengaruhi pertumbuhan karang di lokasi penelitian. Tingkat kecerahan dan kekeruhan yang tidak memenuhi baku mutu mempengaruhi kehidupan fragmen karang Acropora millepora yang transpantasi. Dengan demikian, pertumbuhan fragmen tergolong rendah dengan tingkat persentase kelangsungan hidup yang juga rendah.

\subsection{Pertumbuhan Mutlak Fragmen Karang Acropora millepora}

Pertumbuhan mutlak adalah rata-rata pertumbuhan akhir penelitian di kurangi rata-rata tinggi awal penelitian. Hasil pengukuran pertumbuhan mutlak tinggi karang Acropora millepora selama penelitian disajikan pada Gambar 2.

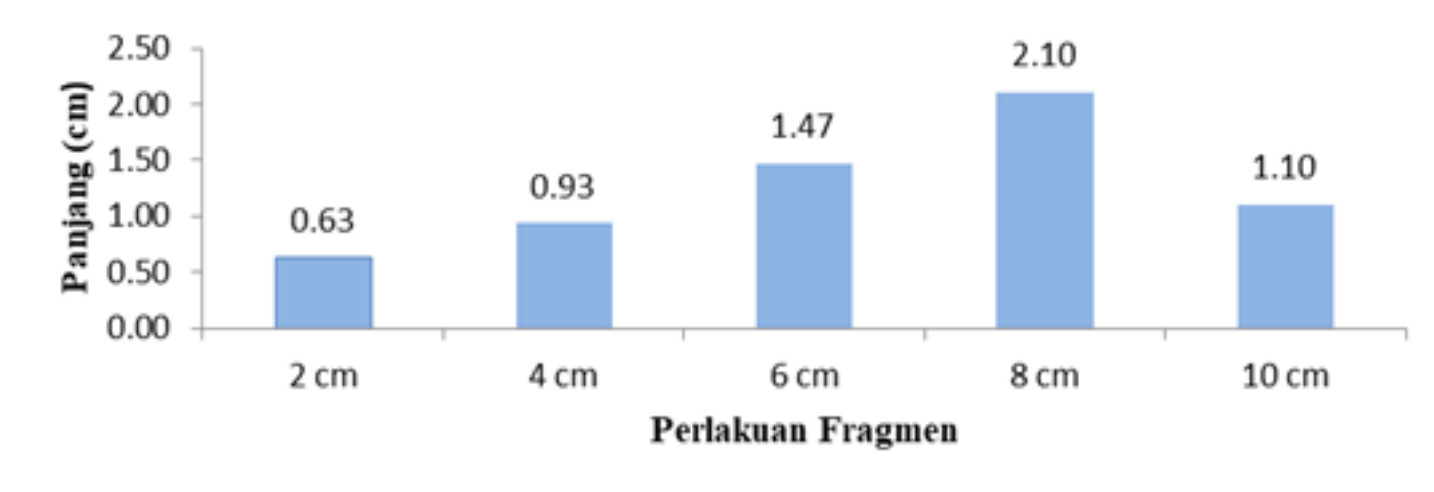

Gambar 2. Pertumbuhan Mutlak Tinggi Karang Acropora millepora

Hasil pengamatan pertumbuhan mutlak fragmen karang Acropora millepora selama tiga bulan penelitian diperoleh bahwa pada perlakuan ukuran fragmen $2 \mathrm{~cm}$ mengalami pertumbuhan rata-rata sebesar 0,63 cm selama 3 bulan pengamatan. Pertumbuhan mutlak pada perlakuan ini merupakan pertumbuhan terendah dibandingkan dengan perlakuan lainnya. Pada perlakuan ukuran fragmen $8 \mathrm{~cm}$ memperoleh angka pertumbuhan mutlak sebesar $2,10 \mathrm{~cm}$ selama masa penelitian ( 3 bulan) dan merupakan pertumbuhan mutlak tertinggi dibandingkan dengan perlakuan lainnya.

Analisis data pertumbuhan mutlak tinggi karang Acropora millepora mengunakan uji One-Way ANOVA dapat dilihat pada Tabel 2. 
Tabel 2. Uji One-Way ANOVA pada Pertumbuhan Mutlak Tinggi Karang Acropora millepora

\begin{tabular}{cccccc} 
Variabel & Sum of Squares & df & Mean Square & F & Sig. \\
Perlakuan & 3,817 & 4 & 0,954 & 36,705 & 0,000 \\
Mutlak tinggi & 0,260 & 10 & 0,026 & & \\
Total & 4,077 & 14 & & & \\
\hline
\end{tabular}

Berdasarkan hasil analisis ujin beda nyata One-Way ANOVA diketahui bahwa nilai F hitung $(36,705)>$ dari F tabel (3,4780). Hal ini menunjukan bahwa terdapat perbedaan nyata dari rata-rata pertumbuhan mutlak tinggi fragmen karang selama penelitian. Oleh karena itu, untuk menguji perbedaan pertumbuhan tinggi mutlak dilakukan uji lanjut Duncan untuk memastikan kesimpulan analisa beda nyata One-Way ANOVA yang telah dianalisis sebelumnya. Hasil uji lanjut Post Hoc Duncan dengan tingkat ketelitian 95\% dapat dilihat pada Tabel 3.

Tabel 3. Hasil Uji Lanjut Post Hoc Duncan Pertumbuhan Mutlak Tinggi Acropora millepora

\begin{tabular}{cccccc} 
Perlakuan & N & \multicolumn{5}{c}{ Subset for alpha $=0.05$} \\
$2 \mathrm{~cm}$ & 3 & 0,6333 & & 3 & \\
$4 \mathrm{~cm}$ & 3 & & 0,9333 & & \\
$10 \mathrm{~cm}$ & 3 & 1,1000 & 1,4667 & 2,1000 \\
$6 \mathrm{~cm}$ & 3 & & & 1,000 & 1,000 \\
$8 \mathrm{~cm}$ & 3 & & & & \\
Sig. & & 1,000 & 0,234 & & \\
\hline
\end{tabular}

Berdasarkan hasil uji lanjut Duncan dengan ketelitian 95\% pada data karang Acropora millepora di dapatkan bahwa nilai perbedaan pertumbuhan mutlak tinggi karang antar perlakuan diperoleh signifikan sebesar 1.000 untuk perlakuan $2 \mathrm{~cm}, 6 \mathrm{~cm}$, dan $8 \mathrm{~cm}$, dan signifikan 0,234 untuk perlakuan $4 \mathrm{~cm}$ dan $10 \mathrm{~cm}$. Hasil analisis Post Hoc Duncan dengan tingkat ketelitian 95\% ini menunjukan bahwa pertumbuhan mutlak tinggi karang Acropora millepora memiliki perbedaan signifikan antara masing-masing perlakuan dan perlakuan karang ukuran $8 \mathrm{~cm}$ memiliki nilai perbedaan terbesar di bandingkan perlakuan yang lain.

\subsection{Laju Pertumbuhan Fragmen Karang Acropora millepora}

Laju pertumbuhan fragmen karang Acropora millepora merupakan selisih pertumbuhan tinggi karang setiap bulan pengamatan dari awal hingga akhir penelitian. Hasil pengukuran laju pertumbuhan tinggi karang Acropora millepora tersaji pada Gambar 3.

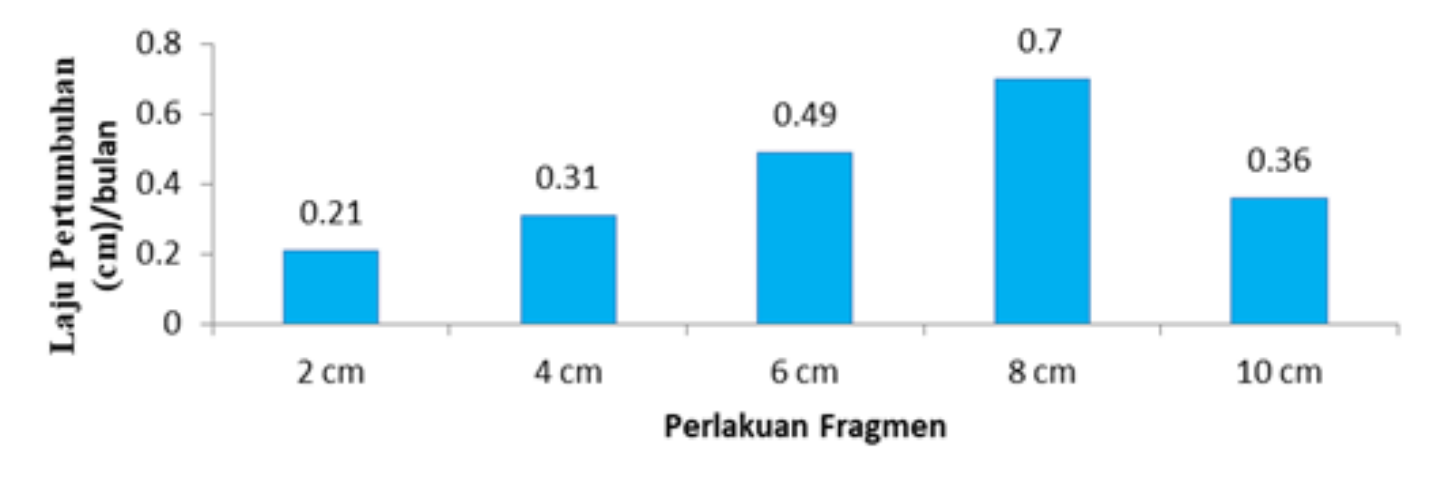

Gambar 3. Laju Pertumbuhan Fragmen karang Acropora millepora

Laju pertumbuhan fragmen karang Acropora millepora untuk semua perlakuan berkisar antara 0,21-0,7 cm/bulan. Jika dilihat dari nilai pertumbuhannya, perlakuan fragmen ukuran $8 \mathrm{~cm}$ memiliki laju pertumbuhan tertinggi sebesar $0,7 \mathrm{~cm} /$ bulan sedangkan perlakuan fragmen ukuran $2 \mathrm{~cm}$ memiliki pertumbuhan terendah sebesar $0,21 \mathrm{~cm} / \mathrm{bulan}$. Perlakuan fragmen yang lebih tinggi, memiliki pertumbuhan yang lebih tinggi pula. Kondisi ini berkaitan dengan jumlah polip karang yang berbeda-beda pada masing-masing pelakuan ukuran fragmen. Berdasarkan hasil kajian Pillay et al. (2005), bahwa fragmen karang Acropora millepora dengan ukuran 4-5 cm umumnya memiliki jumlah koloni rata-rata senesar $3.4 \times 106$ cells $/ \mathrm{cm}^{2}$. Tentunya dengan ukuran fragmen yang lebih panjang, memiliki jumlah polip yang lebih banyak sehingga laju pertumbuhan karang Acropora millepora lebih tinggi. Kondisi ini yang mempengaruhi tingginya pertumbuhan fragmen karang Acropora millepora pada ukuran fragmen yang lebih besar. 
Jika mengacu pada laju pertumbuhan fragmen karang Acropora millepora yang dilakukan oleh Johan et al. (2007), bahwa pertumbuhan karang hias jenis Acropora millepora berkisar antara 0,22-0,88 cm/bulan dengan rata-rata pertumbuhan karang Acropora millepora sebesar 0,58 cm/bulan, selanjutnya penelitian Tioho \& Karauwan (2013), menyebutkan bahwa laju pertumbuhan karang Acropora sp. berkisar antara 0,88-0,94 cm/bulan. Serta penelitian Attalla et al. (2011), menyebutkan bahwa pertumbuhan fragmen karang Acropora sp. berkisar antara 0,58-0,74cm/bulan. Dilihat dari hasil referensi tersebut, kisaran pertumbuhan fragmen karang jenis Acropora millepora pada penelitian ini masih sesuai dengan kisaran pertumbuhan pada umumnya. Namun, pertumbuhan fragmen karang Acropora millepora pada penelitian ini, lebih rendah dibanidngkan dengan literatur-literatur diatas.

Secara keseluruhan, rendahnya pertumbuhan fragmen karang Acropora millepora dipengaruhi oleh kondisi perairan di lokasi penelitian. Seperti nilai kekeruhan perairan di lokasi penelitian berkisar antara 7,21-7,57 NTU lebih tinggi dibandingkan nilai kekeruhan yang diatur oleh Kepmen LH No 51 (2004) yakni sebesar 55 NTU. Kecerahan perairan di lokasi penelitian juga diketahui berkisar antara 2,01-2.59 m. Kecerahan juga terkategorikurang baik karena tidak sesuai dengan baku mutu yang ditentukan Kepmen LH No 51 (2004) yakni sebesar $>5 \mathrm{~m}$.

Kondisi kecerahan air menjadi parameter yang penting untuk menunjang pertumbuhan fragmen karang, karena kecerahan ini berkaitan dengan intensitas cahaya matahari yang masuk ke perairan yang dimanfaatkan oleh polip karang (zooxhantellae) untuk berfotosintesis. Mengacu pada pernyataan Natasasmita et al. (2014), parameter yang mempengaruhi pertumbuhan fragmen karang diantaranya ialah suhu, salinitas, $\mathrm{pH}$, sedimentasi, serta kecerahan air. Lebih lanjut menurut Wijaya et al. (2017), tanpa cahaya yang cukup, laju fotosintesis akan berkurang dan bersama dengan itu kemampuan karang untuk menghasilkan kalsium karbonat dan membentuk terumbu akan berkurang. Jadi, kisaran penetrasi cahaya diatas masih termasuk normal dan dapat mendukung pertumbuhan terumbu karang. Serta menurut Rudi (2008), bahwa zooxanthellae, yang terdapat di dalam tubuh karang tidak dapat hidup dengan baik dan optimalkarena keterbatasan dalam melakukan fotosintesis. Cahaya sangat diperlukan bagi kehidupan karang mulai dari tahap larva sampai dewasa.

Untuk melihat perbedaan pertumbuhan fragmen karang untuk masing-masing perlakuan di lokasi penelitian dianalisis dengan menggunakan uji beda nyata One-Way Anova. Dengan memasukan data Fragmen karang yang masih tersisa dari sisa ulangan dari setiap perlakuan. Hasil uji beda nyata pertumbuhan karang di lokasi penelitian disajikan secara lengkap seperti pada Tabel 4.

Tabel 4. Hasil Uji Beda Nyata One-Way Anova Laju Pertumbuhan Karang Acropora millepora

\begin{tabular}{cccccc} 
& Sum of Squares & df & Mean Square & F & Sig. \\
Laju Pertumbuhan & 0,386 & 4 & 0,096 & 9,535 & 0,002 \\
Tinggi Karang & 0,101 & 10 & 0,010 & & \\
Total & 0,487 & 14 & & \\
\hline
\end{tabular}

Berdasarkan hasil analisis beda nyata One-Way Anova diketahui bahwa nilai F Hitung $(35,718)>$ Dari F Tabel $(3,4780)$. Hal ini menunjukan bahwa hipotesis diterima atau dapat dikatakan terdapat perbedaan yang nyata pertumbuhan fragmen karang Acropora millepora pada masing-masing perlakuan. Sealnjutnya untuk menguji perbedaan pertumbuhan fragmen karang Acropora millepora dilakukan uji lanjut Post Hoc Duncan untuk memastikan kesimpulan analisi beda nyata One-Way Anova yang telah dianalisis sebelumnya. Hasil uji lanjut Post Hoc Duncan disajikan secara rinci seperti pada Tabel 5 .

Tabel 5. Hasil Uji Lanjut Post Hoc Duncan Laju Pertumbuhan Fragmen Karang Acropora millepora

\begin{tabular}{ccccc} 
Perlakuan & N & \multicolumn{3}{c}{ Subset for alpha $=0.05$} \\
$2 \mathrm{~cm}$ & 3 & 0,2100 & 2 & 3 \\
$4 \mathrm{~cm}$ & 3 & 0,3433 & 0,3433 \\
$10 \mathrm{~cm}$ & 3 & 0,3633 & 0,3633 \\
$6 \mathrm{~cm}$ & 3 & & 0,4100 & 0,6967 \\
$8 \mathrm{~cm}$ & 3 & 0,105 & 0,457 & 1,000 \\
Sig. & & & \\
\hline
\end{tabular}

Berdasarkan uji lanjut Post Hot Duncan terdapat perbedaan yang nyata dari pertumbuhan fragmen karang Acropora millepora, didapatkan bahwa nilai perbedaan laju pertumbuhan tinggi karang Acropora millepora antar perlakuan diperoleh nilai signifkan sebsesar 0,105 untuk perlakuan $2 \mathrm{~cm}, 4 \mathrm{~cm}$ dan $10 \mathrm{~cm}$, signifikan 0,457 untuk perlakuan $4 \mathrm{~cm}, 6$ $\mathrm{cm}$ dan $10 \mathrm{~cm}$, dan signifikan 1,000 untuk perlakuan $8 \mathrm{~cm}$. Hasil analisis Post Hoc Duncan dengan tingkat ketelitian 95\% ini menunjukan bahwa nilai perbedaan terbesar terdapat pada kelompok ketiga dan sebagai kelompok pertumbuhan tercepat selama penelitian. 


\subsection{Pengelompokan Tingkat Kelangsungan Hidup Fragmen Karang Acropora millepora}

Kelangsungan hidup adalah seberapa tinggi atau rendahnya tingkat kehidupan karang tanpa mengalami kematian selama penelitian yang dinyatakan dalam satuan persen (\%). Hasil pengamatan tingkat kelangsungan hidup karang dapat dilihat pada Gambar 4.

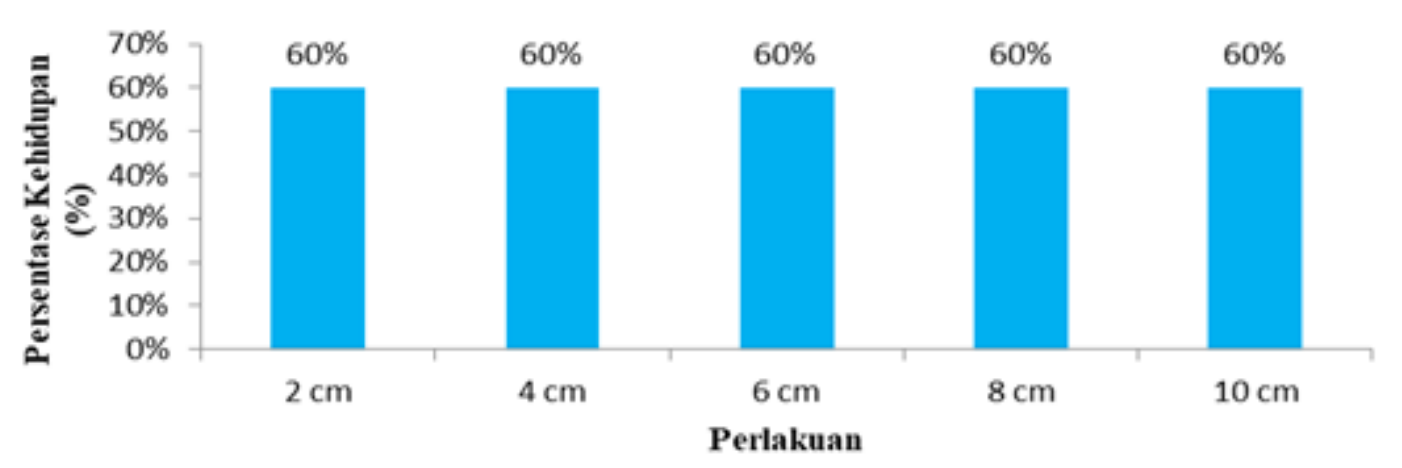

Gambar 4. Tingkat Kelangsungan Hidup Fragmen Karang Acropora millepora

Berdasarkan hasil tingkat kelangsungan hidup karang Acropora millepora, hasil akhir tingkat kelangsungan hidup pada masing-masing perlakuan selama penelitian memilki kelangsungan hidup yang sama sebesar $60 \%$ dan tingkat kematian $40 \%$.

Untuk melihat adanya perbedaan nyata tingkat kelangsungan hidup karang Acropora millepora pada masing-masing perlakuan dianailisis dengan mengunakan One-Way Anova. Hasil dari uji nyata One-Way Anova Tingkat Kelangsungan Hidup karang Acropora millepora terdapat pada Tabel 6.

Tabel 6. Hasil Uji Nyata One-Way Anova Tingkat Kelangsungan Hidup Karang Acropora millepora

\begin{tabular}{ccccc} 
Variabel & Sum of Squares & Df & Mean Square & F \\
Perlakuan & 0.000 & 4 & 0.000 & Sig. \\
Persentase & 0.000 & 10 & 0.000 & \\
Total & 0.000 & 14 & & \\
\hline
\end{tabular}

Berdasarkan hasil uji nyata One-Way ANOVA tingkat kelangsungan hidup karang Acropora millepora tidak didapatkan nilai signifikan. Hal ini menunjukan bahwa nilai F hitung < dari pada F tabel atau dapat dikatakan tingkat kelangsungan hidup karang Acropora millepora pada penelitian ini tidak ada perbedaan nyata (Ho diterima). Hal ini juga bisa dikatakan bahwa tidak perlunya uji lanjut Post Hoc Duncan dikarenakan uji beda nya One-Way Anova hanya menunjukkan apakah terdapat perbedaan atau tidak dari kelompok yang diuji.

Membandingkan hasil penelitian Endo et al. (2006) yakni persentase kelangsungan hidup fragmen Acropora millepora di Pantai Kuta, Bali diperoleh rata-rata persentase kelangsungan hidup sebesar 68\%. Selanjutnya hasil penelitian Arifin dan Luthfi (2016) bahwa kelangsungan hidup karang Acropora sp. Selama penelitian tergolong tinggi dengan nilai ratarata sebesar 88,9\% dan hanya mengalami kematian fragmen sebesar 11,1\%. Dibandingkan dari hasil penelitian tersebut, persentase kelangsungan hidup fragmen karang Acropora millepora di lokasi penelitian tergolong rendah.

Banyak fragmen Acropora millepora yang mengalami kematian disebabkan oleh beberapa faktor diantaranya adanya kerentanan fragemn untuk menyesuaikan diri di lokasi tranplantasi serta pengaruh dari gelombang serta arus air. Selain itu kondisi perairan berupa kecerahan yang kurang baik (tidak sesuai) serta kekeruhan yang kurang baik pula (tidak sesuai) mengambarkan penetrasi cahaya matahari dilokasi penelitian sudah berkurang. Kekeruhan yang tinggi mengambarkan bahwa partikel-partikel yang terlarut di dalam air juga tergolong tinggi sehingga akan mempengaruhi penetrasi cahaya. Dengan demikian cahaya matahari akan terhambat dan berimbas pada tidak optimal nya fotosintesis oleh polip karang, sehingga kehidupan polip karang terganggu. Menurut Rauf et al. (2015), cahaya matahari sangat penting bagi keberadaan zooxanthellae, cahaya digunakan oleh zooxanthellae untuk melakukan fotosintesis. Karena adanya simbiosis mutualisme antara zoohanthellae dan hewan karang maka proses fotosintesis ini sangat penting untuk kehidupan karang maupun hewan lain dan juga keberadaan zooxanthellae nya. Lebih lanjut Thamrin et al. (2004), mengatakan bahwa densitas atau kepadatan zooxanthellae pada karang Acropora millepora berbading terbalik dengan tingkat kekeruhan perairan. Bila tingkat kekeruhan perairan tinggi maka karang Acropora millepora memiliki densitas cahaya yang rendah.

\section{SIMPULAN}

Pertumbuhan mutlak tinggi karang berkisar antara 0,63 cm-2,10 cm, laju pertumbuhan karang berkisar antara 0,21 $\mathrm{cm}-0,70 \mathrm{~cm}$, dan tingkat kelangsungan hidup memiliki tingkat kelangsungan hidup yang sama pada setiap perlakuan 
sebesar 60\%. Fragmen optimal yang diperoleh adalah fragmen karang Acropora millepora dengan ukuran fragmen $8 \mathrm{~cm}$ dengan pola pertumbuhan vertikal dengan tingkat kelangsungan sama, dengan fragmen lainnya. Secara umum, pertumbuhan karang ini didukung oleh kondisi kualitas perairan yang memenuhi standar baku air laut untuk biota laut khususnya biota karang.

\section{UCAPAN TERIMA KASIH}

Penulis mengucapkan terima kasih kepada pihak-pihak yang telah mendanai dan membantu penelitian ini yaitu CSR Department Banyan Tree Resort (Conservation Lab), melalui On The Training and Research Program, serta kami ucapkan terima kasih kepada Pembimbing Lapangan Bapak Renald Yude, S.Pi.

\section{REFERENSI}

Anggara, S.P. (2016). Kondisi Terumbu Karang di Sekitaran Perairan Banyan Tree Bintan Kabupaten Bintan Provinsi Kepulauan Riau. Universitas Riau.

Arifin, Z. \& Luthfi, O.M. (2016). Studi Pertumbuhan dan Survival Rate pada Transplantasi Karang Acropora Sp. di Pantai Kondang Merak Kabupaten Malang. Seminar Nasional Perikanan dan Kelautan VI, Fakultas Perikanan dan Ilmu Kelautan. Universitas Brawijaya Malang: 556-561.

Attala, T.M., Hanafy, M.H., \& Aamer, M. (2011). Growth Rates of The Two reef-Building Species, Acropora humilis and Millepora platyphylla at Hurghada, Red Sea, Egypt. Egypt Journal Aquatic and Fisheries, 15(2): 1-15.

Endo, S., Prasetyo, R., Nishihira, M., \& Onaka, S., (2006). Experimental Coral Transplantation in The Moat of Kuta Beach, Bali Island, Indonesia. Ocean Exposition Commemorative Park, Management Foundation and Meio University : 1-5.

Hermanto, B. (2015). Pertumbuhan Fragmen Acropora formosa pada Ukuran Yang Berbeda Dengan Metode Transplantasi di Perairan Selat Lembeh. Jurnal Ilmiah Platax, 3(2): 90-100.

Johan, O., Hadie, W., Saputra, A., Haryadi, J., \& Listyanto, N. (2007). Budi Daya Karang Hias Mendukung Perdagangan Karang Hias yang Berkesinambungan. Jurnal Riset Akuakultur, 2(3): 415-424.

Kambey, D.A. (2013). The Growth of Hard Coral (Acropora sp.) Tranplants in Coral Reef of Malalayang Waters, North Sulawesi, Indonesia. Jurnal Ilmiah Platax, 1(4): 196-203.

Keputusan Menteri Lingkungan Hidup No. 51 Tahun 2004 Tentang Baku Mutu Air Laut untuk Biota Laut.

Kurniawan, D. (2011). Studi Pertumbuhan dan Tingkat Kelangsungan Hidup Karang Goniopora stokesii (Blainville, 1830) Menggunakan Teknologi Biorock. Universitas Hasanuddin.

Kurniawan, D. (2014). Kajian Laju Pertumbuhan Tahunan dan Distribusi Karang Goniopora stokesi (Milne Edwards and Haime, 1851) di Perairan Pulau Laelae dan Pulau Barranglompo. Universitas Hasanuddin.

Kurniawan, D., Jompa, J., \& Haris, A. (2017). Pertumbuhan Tahunan Karang Goniopora stokesi di Perairan Kota Makassar Hubungannya dengan Faktor Cuaca. Jurnal Akuatiklestari, 1(1): 7-14.

Natasasmita, D., Wijayanti, D.P., \& Suryono, C.A. (2014). Pengaruh Perbedaan Tegangan Listrik (Volt) dan Ukuran Awal Fragmen pada Transplantasi Biorock terhadap Pertumbuhan Karang (Acropora cerealis) di Pantai Pemuteran, Bali. Journal of Marine Research, 3(19): 1-11.

Pillay, R.M., Willis, B., \& Terashima, H. (2005). Trends in the Density of Zooxanthellae in Acropora millepora (Ehrenberg, 1834) at the Palm Island Group, Great Barrier Reef, Australia. Symbiosis, 38(1): 210-226.

Prastiwi, D.I., Soedharma, D., \& Subhan, B. (2012). Pertumbuhan Karang Lunak Lobophytum strictum Hasil Transplantasi pada Sistem Resirkulasi dengan Kondisi Cahaya Berbeda. Bonorowo Wetlands, 2(1): 31-39.

Rauf, K.P., Supriharyono, \& Purnomo, P.W. (2015). Kelimpahan Zooxanthellae pada Acropora sp. Berdasarkan Kedalaman Perairan dan Naungan yang Berbeda di Pulau Pari Kepulauan Seribu Jakarta. Diponegoro Journal of Maquares: Management of Aquatic Resources, 4(1): 46-54.

Rudi, E. (2008). Kajian Rekrutmen Karang Scleractinia di Kepulauan Seribu, DKI Jakarta. Diversitas, 9(1): 39-43.

Santoso, A.D., \& Kardono. (2008). Tekonologi Konservasi dan Rehabilitasi Terumbu Karang. Jurnal Teknologi Lingkungan, 9(3): $121-226$.

Thamrin, Hafiz, M., \& Mulyadi, A. (2004). Pengaruh Kekeruhan Terhadap Densitas Zooxanthellae pada Karang Scleractinia Acropora aspera di Perairan Pulau Mursala dan Pulau Poncan Sibolga, Sumatera Utara. Ilmu Kelautan, 9(2): 82-85.

Tioho, H., \& Karauwan, M.A.J. (2014). Transplantation of coral fragment, Acropora formosa (Scleractinia). Aquatic Science $\mho$ Management, Edisi Khusus (2): 1-7.

Wijaya, C.K., Komala, R., \& Giyanto. (2017). Condition, Diversity, and Growth Forms of Coral in Kayu Angin Genteng Island, Seribu Islands. Bioma, 13(2): 108-118. 